\section{Mechanism of stomatal movement}

ACCORDING to Bowling's malate-switch hypothesis $^{1}$ of stomatal action, the $p \mathrm{H}$ changes in the guard cell create a gradient of monovalent malate towards either guard cells or epidermal cells causing a diffusion of $\mathrm{K}^{+}$(bound to monovalent malate) along with the gradient. His theory is based on (1) changes in $p \mathrm{H}$ of guard cells during opening or closure, (2) balancing of $\mathrm{K}^{+}$by the amounts of malate and chloride present in epidermal tissue, and (3) no change in the net amounts of $\mathrm{K}^{+}, \mathrm{Cl}^{-}$or malate in epidermal tissue.

Changes in the $p \mathrm{H}$ of guard cells do occur ${ }^{2,3}$, however. Malate and $\mathrm{Cl}^{-}$, together, can balance $\mathrm{K}^{+}$present in guard cells ${ }^{4-6}$. There is also no net change in $\mathrm{K}^{+}$ of epidermal tissue ${ }^{7}$. The replaceability of $\mathrm{K}^{+}$by $\mathrm{Na}^{+}$for stomatal opening demonstrated that a monovalent ion is necessary to increase the turgor pressure of guard cells but not necessarily $\mathrm{K}^{+}$ (refs 8-10).

We cannot reconcile these data on malate with the proposals of Bowling ${ }^{1}$. The epidermal tissues produce appreciable quantities of malate and the changes in malate levels are closely and positively correlated with the stomatal aperture ${ }^{5,6,11}$. Further, the epidermal tissues contain highly active enzymes not only for malate synthesis but also for malate degradation $^{12.13}$. The above data, together with the autoradiographic studies indicate that malate production and metabolism could occur in guard cells ${ }^{2,11-13}$. The general understanding is that guard cells can derive malate through phosphoenolpyruvate carboxylation and may exchange those acid ions for $\mathrm{K}^{+}$. The stimulation of stomatal opening by phosphoenolpyruvate $^{13}$ supports this assumption.

In fact, no anion is required for $\mathrm{K}^{+}$ uptake by guard cells since the guard cell can itself release $\mathrm{H}^{+}$ions ${ }^{14}$. We therefore feel that, in addition to malate, photosynthetic and/or respiratory electron transport-mediated $\mathrm{H}^{+} / \mathrm{OH}^{-}$efflux could cause a change in the $p \mathrm{H}$ and provide the necessary $\mathrm{H}^{+}$ions for exchange with $\mathrm{K}^{+}$. We have presented evidence for such lightinduced efflux in guard cells ${ }^{15}$. An active uptake of $\mathrm{K}^{+}$is likely because the stomatal response to even $\mathrm{CO}_{2}$ free air is sensitive to metabolic inhibitors ${ }^{16}$. Abscisic acid also interferes with energy metabolism in guard cells ${ }^{17,18}$. Active $\mathrm{K}^{+}$transport is, however, not ruled out by Bowling ${ }^{1}$.

\section{V.S. R. DAS* \\ I. M. RAO}

A. S. RaghavendRA

Department of Botany,

Sri Venkateswara University,

Tirupati 517 502, India *Present address: School of Life Sciences, University of
Hyderabad, Hyderabad 500,001, India.

Bowling, D. J. F. Nature 262, 393-394 (1976).

Meidner, H. \& Mansfield, T. A. Physiology of Stomata (McGraw-Hill, New York, 1968). enny, M. G. \& Bowling, D. J. F. Planta 122, Raschke, K \& F (1971).

Allaway, W. G. Planta 110, 63-70 (1973).

Pearson, C. J. \& Milthorpe, F. L. Aust. J. P Physiol. 1, 221-236 (1974)

7 Pearson, C. J. Aust. J. Pl. Physiol. 2, 85-89 (1975). Willmer, C. M. \& Mansfield, T. A. New Phytol. 68 363-375 (1969)

Pallaghy, C. K. Z. Pfanzenphysiol. 62, 58-62 (1970)

Raghavendra, A. S.', Rao, I. M. \& Das, V. S. R. Z. Pflanzenphysiol. 80, 36-42 (1976)

Wilimer, C. M. \& Dittrich, P. Planta 117, 123-132 (1974).

Villmer, C. M., Pallas, J. E. \& Black, C. C. $P$ Physiol. Lancaster 52, 448-452 (1973).

Das, V.S. R. \& Raghavendra, A. S. Indian J. exp

Raschke, K. \& Humble, G. D. Planta 115, 47-57 (1973).

Raghavendra, A. S., Rao, I. M

Ann. Bot. 40, 899-901 (1976)

71, 332-334 (1974).

. exp. Bot. 27, 559-564 (1976).

Pl. Sci. Leti. 6, 1] i-115(1976).

BOWLING REPLIES-In developing the malate-switch hypothesis I considered the evidence for a connection between overall malate levels and stomatal aperture quoted by Das, Rao and Raghavendra ${ }^{1}$. I do not think, however, that the evidence is as strong as they imply. For example, Pearson and Milthorpe ${ }^{2}$ showed that with

\section{Matters Arising}

Matters Arising is meant as a vehicle for comment and discussion about papers that appear in Nature. The originator of a Matters Arising contribution should initially send his manuscript to the author of the original paper and both parties should, wherever possible, agree on what is to be submitted. Neither contribution nor reply (if one is necessary) should be longer than 300 words and the briefest of replies, to the effect that a point is taken, should be considered.

a malate concentration of $5 \mu \mathrm{g} \mathrm{mg}^{-1}$ the stomatal aperture ranges from 4 to $24 \mu \mathrm{m}$. Allaway $^{3}$ qualifies his conclusions by stating that his results were obtained after 3-h treatments in light or dark, and questions whether the malate--aperture correlation exists in other conditions. Willmer and Dittrich ${ }^{4}$ found no difference in the rate of incorporation of ${ }^{14} \mathrm{C}$ into malate in the light or the dark by Commelina diffusa. They point out that changes in stomatal aperture seem to be much more rapid than do changes in overall levels of organic acids and other metabolic products.

I put forward the malate-switch hypothesis after realising that there is a transport dimension as well as a metabolic dimension to stomatal functioning. A hypothesis which assumes that stomata open as a result of synthesis of malate in the guard cells and subsequent exchange of $\mathrm{H}^{+}$ions with $\mathrm{K}^{+}$has also to explain how $\mathrm{K}^{+}$moves to the guard cell from three cells away as it does in Commelina communis. An accompanying anion is surely required and on present knowledge this would seem to be malate.

\section{J.F. Bowling}

\section{Department of Scientific and Industrial}

Research,

Grasslands Division,

Private Bay, Palmerston North, New Zealand

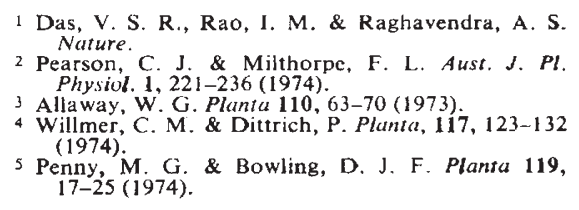

\section{Scrotal asymmetry}

For the record, I report that since reading Morgan and Corballis' on the subject of scrotal asymmetry and Rodin's dyslexia, I have made regular observations of the asymmetry in one person who is right handed, has not got situs inversus totalis (or even partialis), has never had surgical procedures on the abdomen, and has no neurological, endocrinological or psychological disorder, except a certain impatience with pretentious nonsense. My findings are that if the subject of my investigation had been the model for Rodin's L'Age d'Airan, Rodin would have been correct in assigning a lower position to the right testis compared with the left I am not dyslexic.

\section{J. E. Gray}

Department of Anatomy,

University Medical School,

Newcastle upon Tyne, UK

1. Morgan, M. J. \& Corballis, M. C. Nature 264,

This correspondence is now closed. Ed. 